TIGHT OR FLEXIBLE? THE DEGREE OF DETAIL OF LOCAL LAW REGULATIONS AND ITS IMPACT ON A QUALITY OF URBAN SPACE - SELECTED CASES FROM POZNAN

\author{
RYGORYSTYCZNIE CZY ELASTYCZNIE? STOPIEŃ SZCZEGÓŁOWOŚCI \\ ZAPISÓW AKTÓW PRAWA MIEJSCOWEGO I JEJ WPŁYW NA JAKOŚĆ \\ PRZESTRZENI MIEJSKIEJ - WYBRANE PRZYKŁADY Z POZNANIA
}

\title{
Wojciech Skórzewski
}

dr inż. arch.

Author's Orcid number: 0000-0002-2070-9821

Politechnika Poznańska

Wydział Architektury

Instytut Architektury i Planowania Przestrzennego

Zakład Architektury Miejsc Pracy i Rekreacji

\begin{abstract}
Local spatial development plans, are one of the most important urban landscaping tools. Their goal is, on the one hand, to protect urban space including, inter alia, prevention of creation of illconsidered developments, that are bad to the urban landscape, the environment or the local communities. For this purpose, there is a number of restrictions introduced into local spatial development plans. On the other hand, the role of local plans is also creating the space, so they should be conducive to projects with high-quality architecture, that are often unconventional and innovative, adding new value to the architectural landscape of the city, which could be blocked by too strict regulations. The trick is to create regulations in a way that can help reconcile that two goals.
\end{abstract}

Key words: urban planning, zoning plans, local laws.

\section{STRESZCZENIE}

Miejscowe plany zagospodarowania przestrzennego, są jednym z głównych narzędzi kształtowania krajobrazu miasta. Ich celem jest z jednej strony ochrona miejskiej przestrzeni, w tym między innymi zapobieganie powstawaniu inwestycji szkodliwych dla krajobrazu miejskiego, środowiska, czy społeczności lokalnych. W tym celu w planach miejscowych wprowadza się szersze ograniczenia. Z drugiej jednak strony rolą planów jest kreowanie przestrzeni, które powinny sprzyjać przedsięwzięciom o wysokiej jakości architekturze, nierzadko nieszablonowym i nowatorskim, wnoszącym nową wartość w architektoniczny pejzaż miasta, których realizację zbyt rygorystyczne zapisy mogłyby uniemożliwić. Sztuką jest takie stosowanie zapisów, aby umiejętnie pogodzić te dwa cele.

Słowa kluczowe: miejscowe plany zagospodarowania przestrzennego. 


\section{INTRODUCTION}

Local legislation acts, including local spatial development plans, are one of the main tools for shaping the urban (communal, regional) space. They determine the rules of development, which are the constraints for the land owners' or users' activities. The ways these principles are being formulated are the result of various conditions and should take into consideration the most important objectives for spatial planning in general and for specific locations.

One of the crucial goals of spatial policy is to take care of space, which is a common good of the society. From this point of view, spatial planning should take into account such tasks as protection of cultural landscape, natural environment, etc. Therefore, provisions of local acts should protect the space against various adverse actions, especially prevent ill-considered developments, harmful to the cityscape, natural environment or local societies. To this end, local legislation acts introduce a number of qualitative and quantitative restrictions regarding the land use and development. This regulations are often seen as a remedy for the problem of spatial chaos.

On the other hand, the purpose of spatial planning is to create space, including planning new building developments. It is desirable for newly designed investments to perform high quality architecture, bringing a new value to the cityscape. Such a designs are often unconventional and innovative, so excessively too strict and conservative provisions of the local planning acts could not allow to implement such ambitious projects.

So the question arises: how to set up the provisions in planning documents - tight or flexible? The choice of the appropriate approach to planning requires a proper balance between care for the common good and the interest of the owner, between protection of the urban space and creative freedom. It is important to bear in mind the legal framework of the spatial planning system and other circumstances which influence the shape of local spatial development plans, such as financial consequences for the municipal budget or public participation. This article is an attempt to consider the answer to the question posed above. The problem is discussed on the basis of selected examples located in the city of Poznan.

\section{LEGAL SITUATION}

\subsection{Spatial planning system in Poland}

The current spatial planning system in Poland has been introduced by the Act on Spatial Planning and Development of 2003 (Ustawa 2003). According to this Act, the municipality's own responsibilities include the conducting spatial policy within the boundaries of the municipality and it is carried out on the basis of a study of conditions and directions of spatial development.

It is assumed that the fundamental acts of local law, which specify the land use, location of public purpose investments and development conditions, are local spatial development plans (hereinafter referred also to as zoning plans). The scope of provisions in local spatial development plans is set out in legal regulations, in particular Article 15(2) of the Act on Spatial Planning and Development, which lists the issues that have to be obligatorily specified in the plan, and Article 15(3), which provides for optional provisions to be applied depending on the needs. The provisions in zoning plans must not go beyond the framework outlined in the Act, and in particular they should not encroach on the competences of the separate regulations or collide with them.

\subsection{Roles of each planning document}

The roles assigned to each planning document in the Act and the relationships between them determine the manner in which their provisions are created. Thus, they also influence their level of detail, understood as a preferable restrictive or flexible approach.

As mentioned above, the fundamental spatial planning tool in Poland are local spatial development plans. In an area covered with a plan is in force, compliance with its provisions is the basis for granting building permission. Therefore, zoning plans have a direct impact on the shape of the 
emerging buildings - their location, function and size. So far, they have been the final instance to determine the possible land use and shape of development. For this reason, it was sought to make the provisions of the plans sufficiently precise to provide a guarantee of development opportunities for landowners and appropriate, predictable surroundings for their neighbours.

Local spatial development plans have to be in line with the study of conditions and directions of spatial development of the commune (municipality). The study itself does not have the status of a local law, but is a document of the spatial policy of the municipality, created for its internal needs and used mainly by the authors of zoning plans. Therefore, it has only an indirect impact on the character of the emerging development, which is additionally limited only to the areas covered with zoning plans. The decision on land development and management conditions (hereinafter referred also to as planning permission), issued in case of lack of the plan, as well as the decision on the location of a public purpose investment, does not have to be consistent with the study, which content has no impact on the shape of development in the areas not covered by zoning plans. Thus, it may be said that the impact of the study has so far been limited only to the areas covered by the plans, and the bodies bound by the provisions of the study have been the municipalities themselves (council, mayor or town mayor). The planning system conceived this way left no room for a conflict of interests between the authors and users of the study, as it have not posed a risk of interpretation of the study's provisions (e. g. by an investor) contrary to the intentions of its authors. For this reason, the practice of creating provisions of the study has been such as not to restrict the freedom of planners in the face of changing conditions and needs of urban and municipal communities.

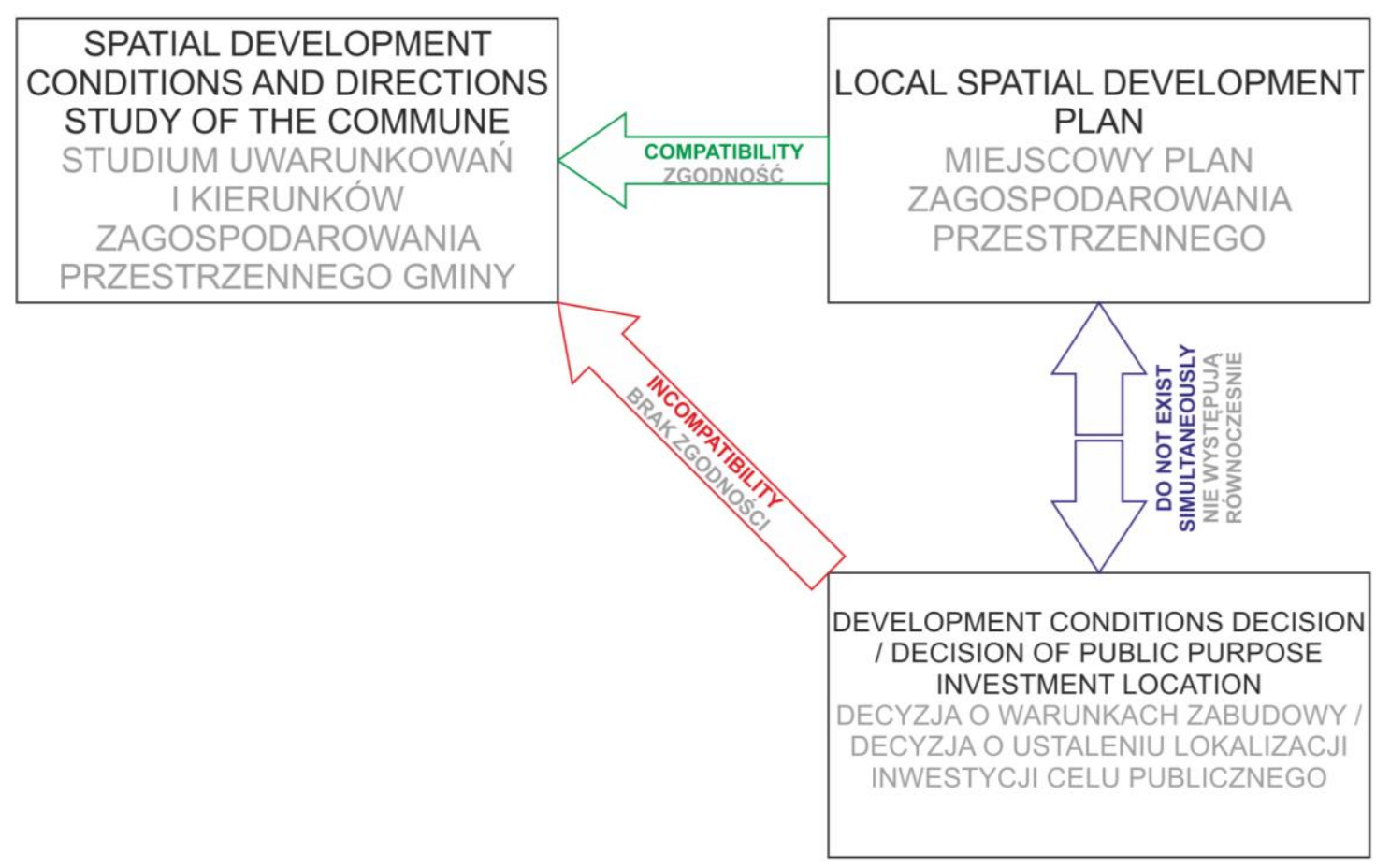

Fig. 1. The diagram of relationships between spatial planning tools before July 5, 2018

Rys. 1. Schemat zależności pomiędzy poszczególnymi narzędziami planowania przestrzennego przed 5 lipca 2018 r. 
The situation has been changed by the adoption of so-called housing special law (Ustawa 2018) in July 2018, giving investors the opportunity to use an additional formal path in the form of a council's Housing Development Location Resolution. The impact of its application on the practice of creating studies and local spatial development plans and the degree of detail of their provisions is not yet known and may be the subject of future research. Nevertheless, it is possible to point out the dependencies between individual spatial planning instruments resulting from the legal regulations. These relationships are shown in the diagrams below in two variants: before (Fig. 1) and after the housing special law came into force (Fig. 2).

It can be seen that adding new spatial shaping tool in the form of a Housing Development Location Resolution creates new dependencies, but also new conflicts. It thus affects the importance of existing planning instruments, strengthening or weakening their effectivity. The role of both the study of conditions and directions for spatial development in the municipality and the local spatial development plans will be redefined.

As far as the study is concerned, it changes its character - it will no longer be only an internal tool of the spatial policy in the municipality, but will have a direct impact on the shape of the housing investment location resolutions issued. For this reason, the protective role of the study will increase as an instrument to secure the space against undesirable actions of investors. Therefore, it may be expected that the municipalities will try to make the provisions of the studies more detailed in order to limit the possibility of their free interpretation.

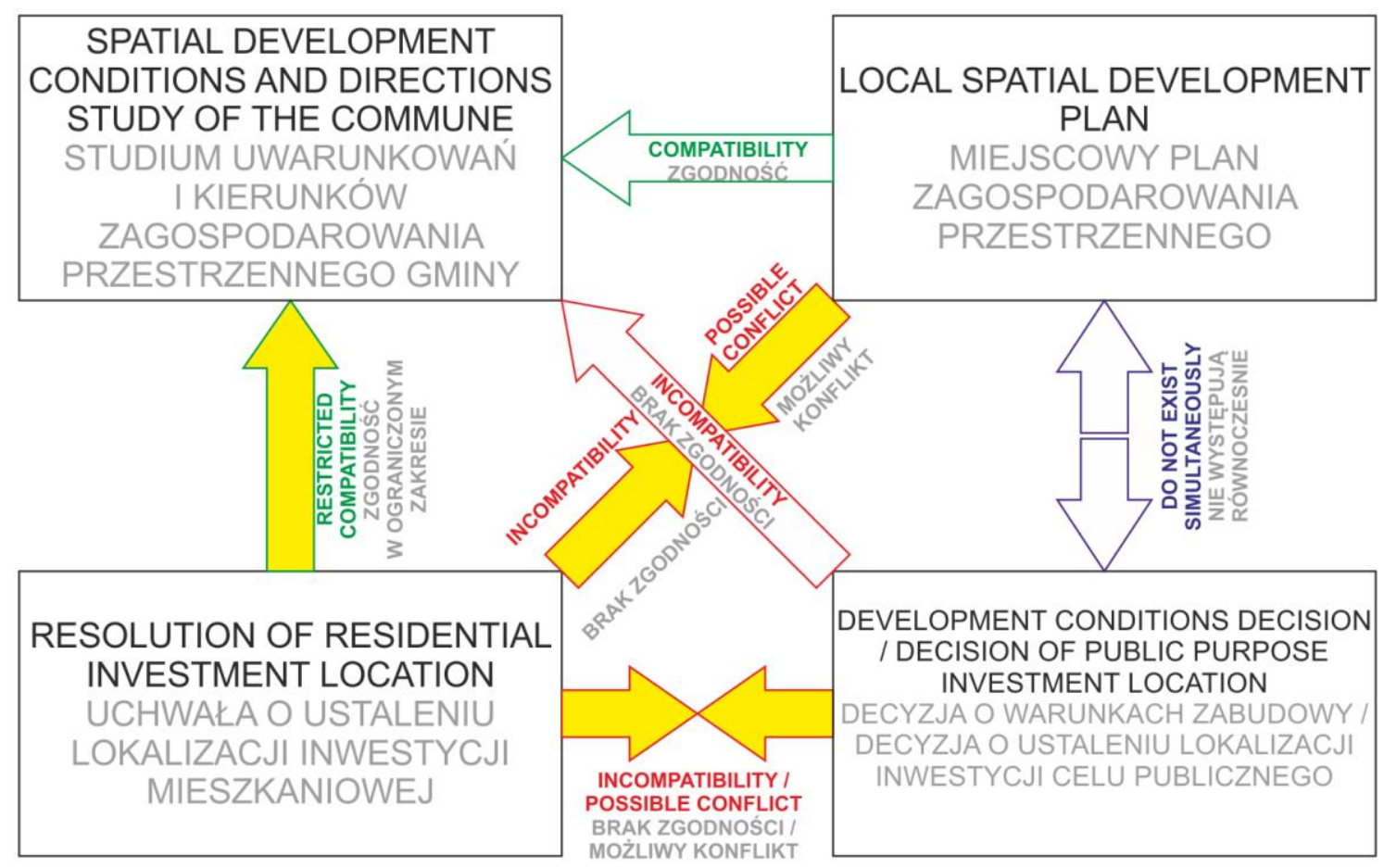

Fig. 2. The diagram of relationships between spatial planning tools after July 5, 2018. i.e. after adopting housing special law Rys. 2. Schemat zależności pomiędzy poszczególnymi narzędziami planowania przestrzennego od 5 lipca 2018 r., tj. po uchwaleniu specustawy mieszkaniowej 
In case of local spatial development plans, we are dealing with the loss of their significance as the ultimate guarantee of certain parameters of space. From then on, it is be possible to issue location resolutions for residential developments which are not in line with the plans. For this reason, the role of zoning plans may weaken - they are no longer a tool which finally decides on development, nor will they ensure a full protection of areas intended as non-buildable. Moreover, the plans will not be the only tool so far to allow large housing developments with sufficient infrastructure, especially in case of lack of any buildings in the neighbourhood. This situation may lead to introducing more liberal provisions in newly adopted plans in order to minimise the risk of using special housing law procedure to carry out developments contrary to the plans. It is difficult to predict whether an additional side effect may be a slowdown in work on new plans due to their lower effectiveness or, on the contrary, an intensification of work on their preparation in order to maintain greater social control (which is much less ensured by the procedure of issuing resolutions under the special housing law).

To assess the actual effects of the implementation of the special housing law, we should wait until the first investments carried out under the special housing law have been completed.

\section{DEGREE OF DETAIL IN ZONING PLANS}

\subsection{Exemplification of restrictiveness or flexibility of plans}

Restrictive or flexible approach to planning can be exemplified in many aspects, among which are plan provisions regarding:

- shaping of build-up lines - as binding or maximum impassable,

- subdivision of land into functional zones, including setting routes of internal (private) roads or or leaving it within the competence of the property owner,

- determining the additional elements of the plan, such as the location of pedestrian routes, green zones or gardens, public space zones, parking areas, suggested locations of dominants and architectural accents,

- defining urban indicators: built-up area ratio, area of biologically active surface, building intensity (currently compulsory to define in the plan) - a very useful tool,

- method of determining the height of buildings,

- introducing solutions that can be implemented with the use of the existing infrastructure or that require the implementation of its new elements (it concerns, for example, the method of ensuring access to a public road).

It should be noted, however, that possibility to change the degree of detail in the plan's provisions is not completely unlimited. On the one hand, Article 15(2) of the Act on spatial planning and development (Ustawa 2003), already mentioned at the beginning, precisely defines the obligatory scope of the content of the local spatial development plan. On the other hand, the plan's provisions should not encroach on issues regulated by separate regulations. This is because there is a risk that the plan may be in conflict with the separate regulations when the regulations are changed, resulting in the need to update the plans each time in such a case. For example, the issue of domestic sewage treatment plants or sealed sewage tanks (septic tanks) - in some of the plans adopted in the past there were provisions restricting their use, however, in accordance with current regulations, these issues cannot be covered by the provisions of the plan. The role of plans is thus limited to strictly urban aspects.

\subsection{Arguments for restrictiveness of plan provisions}

The main reasons for introducing provisions defining possible land use and building parameters in very detailed way are the premises related to the protection of spatial order and cultural heritage, as well as the interests of local communities. The beneficial aspects of precise planning regulations include in particular: 
- reducing the risk of misinterpretation of the planner's intentions,

- reducing the tendency of investors, resulting from economic reasons, to use of excessively acceptable parameters of development (intensity, area or height of buildings) in order to maximize the potential of the plot,

- protection against developments that can be harmful for the surroundings (e.g. in terms of the function) or limit the development possibilities of the neighbours (problem of sun exposure and shading) or those, which can interrupt the opportunities for upgrade and expansion of infrastructure,

- better municipal control over spatial development and, as a consequence, more predictable development.

\subsection{Arguments for flexibility of plan provisions}

Detailed defining of provisions in zoning plans has also disadvantages and may in some cases hinder positive spatial changes. It should be borne in mind that the local spatial development plan is a fairly permanent document in the Polish legal system and its possible change is not easy. The arguments for the flexibility of plan provisions are:

- difficulty to change the plan once adopted, resulting from the long duration of the planning procedure - in Poznan, the procedure of preparing a local spatial development plan takes on average over 3.5 years 1 , and currently 164 plans are being prepared, 43 of which are changes to existing plans2,

- a risk of the plan becoming outdated quickly in case of rapidly changing circumstances: current trends in architecture, situation on the real estate market, needs of investors or citizens and other factors,

- limitation of creative freedom of architects by overly strict provisions, that may, as a result, block unconventional and innovative design solutions,

- increased risk of the property owners' financial claims against the municipality due to blocking or limiting the possibility of using the property in the existing manner (Act 2003, art. $36 \mathrm{sec}$. 1) in the case of provisions that strongly limit the possibilities of plot development - flexible provisions give the owners the possibility of greater freedom in use their property right, therefore such provisions can count on greater public support at the stage of plan preparation, which results in a smaller number of potential negative opinions or remarks submitted to the draft plan and, as a consequence, shortening the planning procedure.

\subsection{Non-planning tools for shaping space}

In the situation, when, for the reasons mentioned above, the detailed definition of the shape of planned development in the zoning plan is not recommended, there are other possible methods of shaping the urban space. These are so-called informal planning tools, also known as soft planning. (Kaczmarek, T.: 2017, ) They are especially useful at the very initial stage of planning the development, when detailed definition of building parameters in the local spatial development plan is usually not yet possible. Working out a common vision of development by the municipality, the investor (property owner) and the inhabitants through cooperation with the use of informal planning tools (e.g. consultations, workshops, etc.) may allow to avoid potential social conflicts. It also allows for a more flexible approach to planning issues, removing some of the burden of responsibility for the shape of space from the provisions of local plans.

Another important factor that can help to shape space is economy. The choice of certain design solutions may result from economic calculation and does not necessarily have to be the subject of detailed solutions in the local spatial development plan. Appropriately formulated provisions of the

\footnotetext{
${ }^{1}$ Average duration of the planning procedure from the resolution on initiation to prepare local spatial development plan until adopting the plan in Poznan was 1326 days according to the data from MPU for 256 local spatial development plans adopted from 16th June 1998 to 8th January 2019.

${ }^{2}$ According to the registry of local spatial development plans by MPU in Poznan on the website mpu.pl - status actual for 21st November 2018.
} 
plan, as well as a well-designed urban layout, should favor such solutions that, while ensuring the profitability of investments, at the same time promote good quality of space. It is a kind of selfregulation of space under the influence of economic factors.

\subsection{Types of local spatial development plans according to the purpose of their preparation}

Depending on the purpose of preparation, the following types of local spatial development plans can be distinguished:

- Protection plans - prepared in order to protect valuable natural areas (e.g. green wedges), landscape and scenic values (e.g. city panoramas) or cultural heritage (e.g. historical city centres or districts, former village layouts or manor farm layouts). They often define non-buildable areas and - in already built-up areas - contain provisions protecting the existing buildings and minimizing the expansion or introduction of new buildings.

- Regulatory plans - prepared in order to improve the functionality and spatial order of urban areas created, for example, without a plan as a result of a decision on development conditions, without sufficient infrastructure, or with functional conflicts (e.g. neighbourhood of an apartment - burdensome industry).

- Investment plans - prepared in order to launch areas for new development: in previously undeveloped areas (e.g. areas that change the status from agricultural to residential) or remediated areas with other functions (e.g. post-industrial, post-railway, former horticultural farms, etc.).

Each of the types listed above needs to introduce the other kind of provisions, use of more restrictive or more flexible approach, depending on expected effects.

\section{RESEARCH MATERIAL AND METHODS}

The research material are the local spatial development plans prepared in accordance with the Act currently in force (Ustawa 2003), which in recent years have been subject to amendments or for which an amendment is currently being proceeded. The initiation of the plan amendment proves that the existing provisions of the plan, including their level of detail, have failed or ceased to be effective in view of the current spatial situation and needs. Such definition of the research material lets us to know the directions of changes in the plan provisions and their causes. Each resolution on plan amendment has a justification which indicates, inter alia, the applicant, the reasons for and objectives of the change. This information is helpful in determining the assumed directions of making the provisions of the plan more restrictive or flexible. In the case of plans that are at a more advanced stage of preparation, we have even more detailed material providing information on this subject in the form of draft amendments to plans and materials from public consultations.

Due to the availability of data and the professional experience of the author, who had the opportunity to work in the Municipal Urban Planning Office (MPU) in Poznan, it was decided to select the amendments of the plans from the area of the city of Poznan. For this purpose, a search was conducted in the register of adopted local spatial development plans and proceeded amendments to plans, including the following documents:

- texts of resolutions on the local spatial development plan with a graphic attachment (before amendments),

- texts of resolutions on the local spatial development plan with a graphic attachment (after amendments),

- texts of resolutions on initiation of the amendment of the local spatial development plan with justification,

- presentations from the public consultations, including draft plans, explanation of the reasons for the plan amendment and planned directions of changes, resolution of requests and opinions to the draft plan,

- draft plans put up to the public together with the submitted remarks and their resolution. 
The information gathered above was used to conduct a comparative analysis of the plans before and after the changes, including:

- determining whether the changes and the reasons for them relate to the level of detail in the plans,

- comparison of the degree of detail (restrictiveness or flexibility) of plan provisions before and after changes,

- finding the dominant trend in the formulation of plan provisions (if can be observed),

- determining the dependence of the direction of changes in the plans depending on the purpose for which they were prepared.

\section{CASE STUDY}

The issue of degree of detail in plan provisions has been analysed on the example of local spatial development plans in Poznan, which has been changed in recent years or which change has been proceeded. The subject of the analysis has been 24 currently processed plan amendments ${ }^{3}$. The analysis is focused on the justifications of resolutions on preparation of plan amendments and, where possible, draft plans presented during public consultations. In several cases the plans have been changed more than once.

Analysing the reasons for proceeding with the changes to plans taken into account, it was found:

- 17 cases of amendments proceeded in order to make provisions more flexible,

- 2 cases of amendments proceeded in order to make provisions more restrictive,

- 1 case in which the flexibility of some provisions was compensated by provisions protecting the space in a different way,

- 3 cases of neutral changes in terms of degree of detail, including updates of the provisions of local spatial development plans in order to ensure compliance with the amended study of conditions and directions of spatial development,

- in 1 case the justification of the amendment has not been available.

Among local spatial development plan amendments listed above, several examples nave been chosen to illustrate the following situations:

- cases in which too restrictive provisions did not prove useful, so it was decided to change the plan in order to make them more flexible,

- cases in which the provisions was too flexible and the necessity to specify them more precise occurred,

- cases in which compromise measures have been introduced to compensate increased flexibility of several provisions with strengthening restrictiveness of the others.

\subsection{Examples of increased flexibility of the provisions in local spatial development plans}

An example of the location, where the provisions of the plan turned out to be too detailed can be the area between Hetmańska, Górecka, Krauthofera i Dmowskiego streets in Poznan. The need to make the planning rules for this area more flexible occurred twice in recent years. In 2005 Local spatial development plan for area of streets: Hetmańskaj, Dmowskiego, J. Krauthofera - Krotowskiego and designed Nowa Opolska in Poznan (Miejscowy plan 2005) (Fig. 3) was adopted. The plan provided a realization of commercial development with precisely specified location of buildings and such elements, like: parts of buildings with elevated height, dominants and architectural accents, passages through buildings, rows of trees, water reservoirs (surface waters), internal roads with access for passenger and freight traffic, etc. Because this concept had been abandoned, the plan became outdated, and the aforementioned level of detail made it impossible to implement any oth-

\footnotetext{
${ }^{3}$ Based on the registry of local spatial development plans by MPU in Poznan and presentations from public consultations
} available on the website of MPU in Poznan - www.mpu.pl - access 21st November 2018. 
er concept different from the original design. Therefore, 5 years later, in 2010 , the amendment to the local spatial development plan was adopted (Zmiana miejscowego planu 2010) (Fig. 4), that contained much more universal provisions. Most of the aforementioned detailed regulations have been removed, leaving only one internal road and a public space zone, the indication of elevated portions of buildings has been replaced with a single zone of higher development.

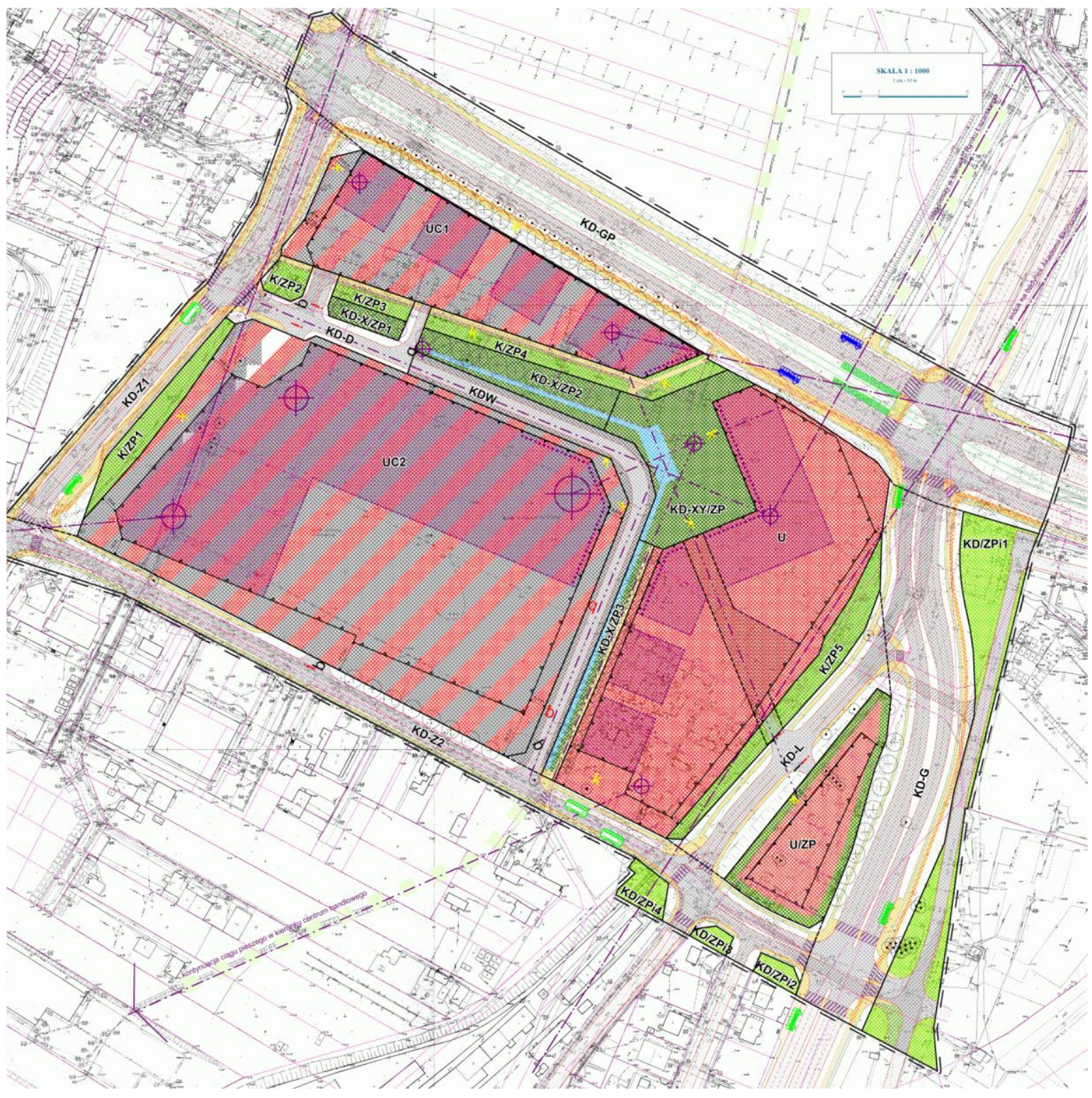

Fig. 3. Fragment of a drawing of the Local Spatial Development Plan in the area of Hetmańska, R. Dmowskiego, J. Krauthofera-Krotowskiego and designed Nowa Opolska Street in Poznan from 2005. Source: Miejska Pracownia Urbanistyczna, Poznan

Rys. 3. Fragment rysunku Miejscowego planu zagospodarowania przestrzennego w rejonie ulic: Hetmańskiej, R. Dmowskiego, J. Krauthofera - Krotowskiego i projektowanej Nowej Opolskiej w Poznaniu z 2005 r. Żródło: Miejska Pracownia Urbanistyczna w Poznaniu 


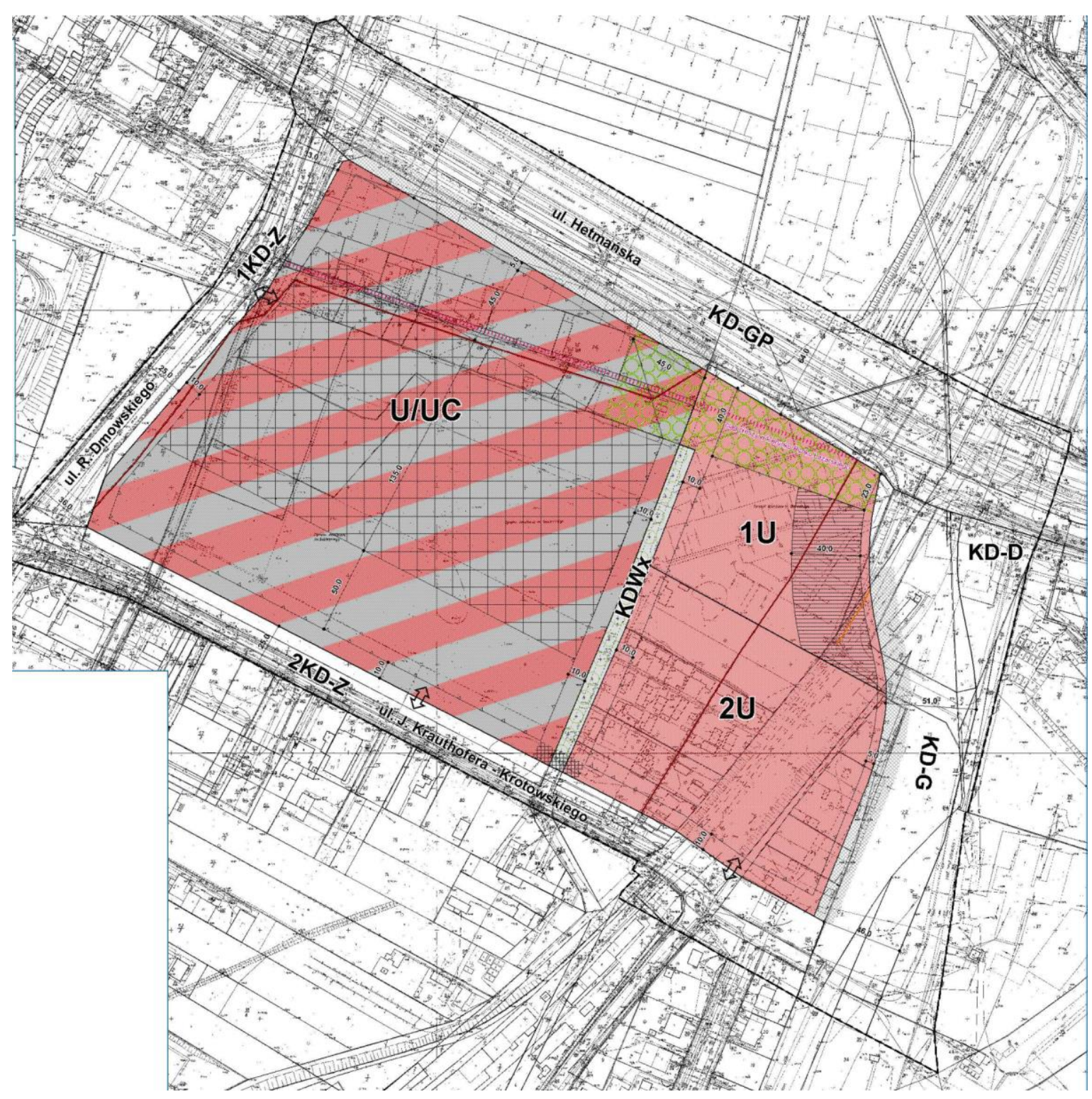

Fig. 4. Fragment of a drawing of theAmendment of Local Spatial Development Plan in the area of Hetmańska, R. Dmowskiego, J. Krauthofera-Krotowskiego and designed Nowa Opolska Street in Poznan from 2010. Source: Miejska Pracownia Urbanistyczna, Poznan

Rys. 4. Fragment rysunku Zmiany miejscowego planu zagospodarowania przestrzennego w rejonie ulic: Hetmańskiej, R. Dmowskiego, J. Krauthofera - Krotowskiego i projektowanej Nowej Opolskiej w Poznaniu z 2010 r. Źródło: Miejska Pracownia Urbanistyczna w Poznaniu

In 2018 on the part of this area, the council started proceeding another amendment to the plan („Rejon ulic Hetmańskiej i Góreckiej” w Poznaniu) (Uchwała 2018, 1), which was caused by, among others, no possibility to build-up the area due to the lack of access to the public road until the planned Nowa Opolska Street is built.

In fact, the previously existing provision made the building development dependent on the construction of infrastructure, which could leave these areas frozen for many years (in the local spatial development plan it is not possible to introduce the demand to implement investments in stages, because it is a local law, not an implementation plan). The envisaged changes are also intended to 
increase the value and attractiveness of the property intended for commercial functions, so further flexibility of provisions is to be expected.

Another example is the Local spatial development plan "Old Town area in Poznan" from 2002 (Miejscowy plan 2002). This plan has been adopted before the current Law on Planning and Spatial Development came into force and was intended as a protection plan, introducing a number of very detailed provisions. The plan has defined, inter alia, the percentage share of housing and commercial functions, which intention was to prevent the depopulation of the historic center leading to its transformation to a mono-functional commercial district. In the case of some plots of land, such a provision has in practice blocked the possibility of their development. The lack of approval for the construction of underground car parks for some areas had a similar effect. For these reasons, in the following years there were several amendments to the plan proceeded for individual fragments (12 plans adopted until 2018, accession to another 4), and in 2018 the city council adopted a resolution to prepare amendment of the the entire plan. (Uchwała 2018,2)

\subsection{Examples of strengthening provisions in local spatial development plans}

The need to strengthen the provisions occurs usually if there is a risk of over-interpretation of them. This is the case, among others, in unusual situations, requiring additional specification of requirements.

These are e.g. the areas with diversified relief, which give a lot of room for interpretation of the provisions regarding the height of the buildings. In such situations, commonly used ways of defining the height of a building in meters or the number of on-ground storeys does not always work. The situation is even more complicated when the designers' intention is to introduce buildings of different heights. Provisions introducing "cascade development" (or named similarly) are imprecise. In such cases, an interesting solution is to define zones with permissible absolute altitude above sea level measured in meters. In Poznan, such a situation occurs, for example, in the draft of the local zoning plan for the area of Minikowo in Poznan (Uchwała 2005), covering the areas located on the slope along the river Warta.

Introducing more restrictive provisions may also be caused by the strive for order in the urban space, making the urban layout more clear. This is the case, for example, of the draft local spatial development plan "Łacina - Południe - Part B" in Poznan (Uchwała 2016), which proposes to replace some of the maximum impassable built-up lines from with the binding built-up lines in order to create frontages along the streets. (Projekt Łacina - Południe - część B 2018)

\subsection{Compromise solutions}

It is often necessary to find intermediate solutions, reconciling seemingly opposing interests, such as protection of the spatial layout and ensuring the possibility of adapting the development to new needs at the same time. A good example of such actions are the local zoning plans for modernist housing estates in Poznan, located in Piątkowo, Winogrady and Rataje. There is a characteristic way of defining build-up lines in these plans - as maximum impassable ones, set back a small distance from the existing building facades. Such a way of shaping the building lines allows to preserve the originally designed spatial layout of the buildings and protect against uncontrolled overdevelopment of residential areas, and at the same time does not block their necessary modernization.

Another example of a compromise between the flexibility and restrictiveness of zoninig plan provisions are situations where the flexibility of some provisions is compensated by the introduction of other restrictions. An example of such situation is the change to the local zoning plan for the area of Poznan International Fair (Uchwała 2017) which is currently under development. In relation to the plan currently in force (Miejscowy plan 2011), the project presented during public consultations (Projekt Miejscowego planu 2018) proposes, among others, to reduce the no-buildable zones, which could result in reduced visibility of the height dominant, which is the market spire (Pavilion No. 11). To counteract this, a Dominant View Protection Zone has been introduced. 


\section{CONCLUSION}

After analysing selected amendments of the local spatial development plans, the following observations can be made:

- the degree of detail in the plans is subject to legal constraints and the progress in standardisation,

- an approach to the degree of detail depends on the purpose of preparation of the plan stronger provisions are desirable in the case of protection and regulatory plans, greater flexibility in the case of investment plans,

- among amendments of plans currently proceeded in Poznan, the vast majority are aimed at making their provisions more flexible,

- too restrictive provisions may lead to block developments in case of investment plans and unable to modernise or complement the existing developments in case of protection and regulatory plans,

- more detailed provisions, e.g. regarding the definition of build-up lines, are a good tool for making the urban composition more clear, especially helpful in the case of regulatory plans,

- making several provisions more flexible can be compensated with introducing the other detailed regulations, for example in order to protect valuable elements of the space.

In general, it should be stated that the degree of detail in local spatial development plans should be determined on a case-by-case basis, taking into account, on the one hand, the objectives to be achieved by the adoption of the plan and, on the other hand, the risks associated with the introduction of particular provisions. In the coming years, we can expect some changes in the approach to the detail of formulating provisions in local plans due to the introduction of a new legal instrument in the form of decisions based on housing special law. The impact of the application of this law on the practice of creating local spatial development plans is not yet known and should be the subject of future research.

\section{RYGORYSTYCZNIE CZY ELASTYCZNIE? STOPIEŃ SZCZEGÓŁOWOŚCI ZAPISÓW AKTÓW PRAWA MIEJSCOWEGO I JEJ WPŁYW NA JAKOŚĆ PRZESTRZENI MIEJSKIEJ - WYBRANE PRZYKŁADY Z POZNANIA}

\section{WSTĘP}

Akty prawa miejscowego, do których należą miejscowe plany zagospodarowania przestrzennego, są jednym z głównych narzędzi kształtowania przestrzeni miasta (gminy, regionu itp.). Określają one zasady zagospodarowania, w tym zabudowy, w ramach których mogą poruszać się właściciele lub użytkownicy terenu. Sposoby formułowania tych zasad są wynikiem różnych uwarunkowań i powinny uwzględniać najważniejsze cele stawiane przed planowaniem przestrzennym ogólnie i w odniesieniu do konkretnych lokalizacji. 
Jednym z podstawowych celów prowadzenia polityki przestrzennej jest dbałość o przestrzeń, która jest dobrem wspólnym społeczeństwa. $Z$ tego punktu widzenia planowanie przestrzenne powinno uwzględniać takie zadania, jak ochrona krajobrazu kulturowego, środowiska przyrodniczego itp. Dlatego też zapisy prawa miejscowego powinny chronić przestrzeń przed różnego rodzaju niekorzystnymi działaniami, a w szczególności zapobiegać powstawaniu inwestycji nieprzemyślanych, szkodliwych dla krajobrazu miejskiego, środowiska, czy społeczności lokalnych. W tym celu w aktach prawa miejscowego wprowadza się szereg ograniczeń jakościowych i ilościowych dotyczących sposobu zagospodarowania i zabudowy. Często upatruje się w nich remedium na problem chaosu przestrzennego.

$Z$ drugiej jednak strony rolą planowania przestrzennego jest kreowanie przestrzeni, $w$ tym też nowej zabudowy. Pożądane jest, aby nowo projektowane inwestycje charakteryzowały się wysoką jakością architektury, wnoszącą nową wartość w architektoniczny pejzaż miasta. Nierzadko są to projekty nieszablonowe i nowatorskie, dlatego też zbyt rygorystyczne, a zwłaszcza zbyt zachowawcze zapisy prawa miejscowego mogłyby uniemożliwić realizację tego typu ambitnych przedsięwzięć.

Pojawia się więc pytanie: jak należy konstruować zapisy dokumentów planistycznych - rygorystycznie czy elastycznie? Wybór odpowiedniego podejścia do planowania wymaga właściwego wyważenia pomiędzy dbałością o dobro wspólne a interesem właściciela, między ochroną przestrzeni a swobodą twórczą. Należy przy tym pamiętać o ramach prawnych systemu planowania przestrzennego oraz o innych uwarunkowaniach, które mają wpływ na kształtowanie planów miejscowych, takich jak skutki finansowe dla gminy, czy partycypacja społeczna. W niniejszym artykule podjęta zostanie próba zastanowienia się nad odpowiedzią na postawione wyżej pytanie. Problem zostanie omówiony na wybranych przykładach zlokalizowanych na terenie miasta Poznania.

\section{STAN PRAWNY}

\subsection{System planowania przestrzennego w Polsce}

Obowiązujący obecnie w Polsce system planowania przestrzennego wprowadzony został Ustawą z 2003 roku o planowaniu i zagospodarowaniu przestrzennym (Ustawa 2003). Wedle tej ustawy prowadzenie polityki przestrzennej na terenie gminy należy do zadań własnych gminy i odbywa się w oparciu o studium uwarunkowań i kierunków zagospodarowania przestrzennego gminy.

W założeniu podstawowym aktem prawa miejscowego, określającym przeznaczenie terenu, rozmieszczenie inwestycji celu publicznego, sposoby zagospodarowania i warunki zabudowy, jest miejscowy plan zagospodarowania przestrzennego. Zakres zapisów miejscowych planów zagospodarowania przestrzennego regulowany jest przez przepisy prawne, w szczególności art. 15 ust. 2 Ustawy o planowaniu i zagospodarowaniu przestrzennym, w którym wymienione są zagadnienia, które muszą być obowiązkowo określone w planie, oraz ust. 3, w którym wyszczególnione sa zapisy fakultatywne, stosowane w zależności od potrzeb. Zapisy planów miejscowych nie powinny wychodzić poza ramy nakreślone w ustawie, a w szczególności nie mogą wchodzić w kompetencje przepisów odrębnych, ani wchodzić z nimi w kolizję.

\subsection{Rola poszczególnych dokumentów planistycznych}

Przypisane w ustawie role poszczególnych dokumentów planistycznych oraz zależności pomiędzy nimi determinują sposób konstruowania ich zapisów. Tym samym wpływają też na ich szczegółowość rozumianą jako preferowane podejście restrykcyjne bądź elastyczne.

Jak już wspomniano wyżej, podstawowym narzędziem planowania przestrzennego w Polsce są miejscowe plany zagospodarowania przestrzennego. Na obszarze, gdzie obowiązuje plan, zgodność $z$ jego zapisami jest podstawą wydania pozwolenia na budowę. Plany miejscowe mają zatem bezpośrednie przełożenie na kształt powstającej zabudowy - jej lokalizację, funkcję, gabaryty. Dotąd były więc ostateczną instancją przesądzającą o możliwym sposobie zagospodarowania terenu i charakterze zabudowy. $Z$ tego powodu dążono do tego, aby zapisy planów były na tyle do- 
precyzowane, aby stanowiły gwarancję możliwości zagospodarowania dla właścicieli gruntów i odpowiedniego otoczenia dla ich sąsiadów.

Miejscowe plany zagospodarowania przestrzennego muszą być zgodne ze studium uwarunkowań i kierunków zagospodarowania przestrzennego gminy. Samo studium nie ma mocy prawa miejscowego, lecz jest dokumentem polityki przestrzennej gminy, tworzonym na jej wewnętrzne potrzeby i używanym przede wszystkim przez projektantów planów miejscowych. Ma ono więc tylko pośredni wpływ na charakter powstającej zabudowy, dodatkowo ograniczony tylko do obszarów pokrytych planami miejscowymi. Wydawana w przypadku braku planu decyzja o warunkach zabudowy, podobnie jak decyzja o ustaleniu lokalizacji inwestycji celu publicznego nie musi być zgodna ze studium, zatem jego treść nie ma wpływu na kształt zabudowy na terenach nie objętych planami miejscowymi. Można więc powiedzieć, że oddziaływanie studium ograniczało się do tej pory tylko do obszarów pokrytych planami, a organami związanymi zapisami studium były wyłącznie same władze gminy (rada, wójt, burmistrz lub prezydent miasta). Tak skonstruowany system planowania nie dawał pola do konfliktu interesów pomiędzy twórcami studium a jego użytkownikami, gdyż nie stwarzał ryzyka interpretacji zapisów studium (np. przez inwestora) sprzecznej z intencjami jego twórców. Z tego powodu praktyka tworzenia zapisów studium była taka, by nie ograniczać swobody planistom wobec zmieniających się warunków i potrzeb społeczności miast i gmin.

Sytuacje zmienia uchwalenie tzw. specustawy mieszkaniowej (Ustawa 2018) w lipcu 2018 r., dającej inwestorom możliwość skorzystania z dodatkowej ścieżki formalnej w postaci Uchwały o ustaleniu lokalizacji inwestycji mieszkaniowej. Wpływ jej stosowania na praktykę tworzenia studium i miejscowych planów zagospodarowania przestrzennego oraz szczegółowość ich zapisów nie jest jeszcze znany i może być przedmiotem przyszłych badań. Niemniej można wskazać wynikające $z$ przepisów prawa zależności pomiędzy poszczególnymi instrumentami planowania przestrzennego. Zależności te przedstawiono na poniższych schematach w dwóch wariantach: przed (Fig. 1) i po wejściu w życie ustawy (Fig. 2).

Można zauważyć, że dodanie nowego narzędzia kształtowania przestrzeni w postaci Uchwały o ustaleniu lokalizacji inwestycji mieszkaniowej tworzy nowe zależności, ale także nowe konflikty. Wpływa w ten sposób na znaczenie dotychczasowych instrumentów planowania, wzmacniając lub osłabiając ich działanie. Przedefiniowaniu ulega rola zarówno studium uwarunkowań i kierunków zagospodarowania przestrzennego gminy, jak i miejscowych planów zagospodarowania przestrzennego.

W przypadku studium zmienia się jego charakter - nie będzie ono już tylko wewnętrznym narzędziem polityki przestrzennej gmin, a zyska bezpośrednie przełożenie na kształt wydawanych uchwał lokalizacyjnych inwestycji mieszkaniowych. $Z$ tego powodu wzrośnie jego rola jako instrumentu zabezpieczającego przestrzeń przed niepożądanymi działaniami inwestorów. Można się więc spodziewać, że gminy będą dążyć do uszczegółowienia zapisów studiów, tak by zawęzić możliwość ich dowolnej interpretacji.

Z kolei w przypadku miejscowych planów zagospodarowania przestrzennego można mówić o zatarciu jego znaczenia jako ostatecznej instancji gwarantującej pewne parametry przestrzeni. Odtąd będzie możliwe wydanie niezgodnych z planami uchwał lokalizacyjnych dla inwestycji mieszkaniowych. Z tego powodu rola planów miejscowych może ulec osłabieniu - nie będą już narzędziem ostatecznie przesądzającym o zagospodarowaniu, ani też nie zapewnią stuprocentowej ochrony terenów nieprzeznaczonych pod zabudowę. Plany nie będą też jak do tej pory jedynym narzędziem pozwalającym na realizację dużych zamierzeń inwestycyjnych wraz z odpowiednią infrastrukturą, zwłaszcza w przypadku braku sąsiedztwa. Taka sytuacja może prowadzić do definiowania swobodniejszych zapisów w nowo uchwalanych planach, aby zminimalizować ryzyko sięgania po procedurę $\mathrm{w}$ trybie specustawy w celu realizacji inwestycji sprzecznych z obowiązującymi planami. Trudno przewidywać czy dodatkowym skutkiem ubocznym może być wyhamowanie prac nad nowymi planami wobec ich mniejszej skuteczności, czy też wręcz przeciwnie - intensyfikacja prac nad ich sporządzaniem w celu zachowania większej kontroli społecznej (którą procedura wydawania uchwał w trybie specustawy zapewnia w dużo mniejszym stopniu).

Na ocenę rzeczywistych skutków wprowadzenia specustawy mieszkaniowej wypada poczekać do realizacji pierwszych inwestycji przeprowadzonych w trybie specustawy. 


\section{SZCZEGÓŁOWOŚĆ ZAPISÓW PLANÓW}

\subsection{Przejawy restrykcyjności lub elastyczności planów}

Podejście restrykcyjne bądź elastyczne może przejawiać się w wielu aspektach, wśród których należy wymienić ustalenia planu dotyczące $\mathrm{m}$. in.:

- kształtowania linii zabudowy - jako obowiązujących lub maksymalnych nieprzekraczalnych,

- podziału na tereny, w tym wyznaczania przebiegu dróg wewnętrznych lub dowolności w tym zakresie,

- wyznaczania dodatkowych elementów planu, takich jak lokalizacja ciągów pieszych, stref zieleni lub ogrodów, stref przestrzeni publicznych, stref lokalizacji parkingów, sugerowanych lokalizacji dominant i akcentów architektonicznych,

- definiowania wskaźników urbanistycznych: procentu zabudowy i powierzchni biologicznie czynnej, intensywności zabudowy (od niedawna obowiązkowej) - bardzo potrzebne narzędzie,

- sposobu określania wysokości budynków,

- wprowadzania rozwiązań dających się zrealizować przy wykorzystaniu istniejącej infrastruktury bądź wymagających realizacji nowych jej elementów (dotyczy np. sposobu zapewnienia dostępu do drogi publicznej).

Należy jednak zauważyć, że w regulowaniu szczegółowości zapisów planu nie ma pełnej dowolności. Z jednej strony wspomniany już na początku art. 15 ust. 2 Ustawy o planowaniu i zagospodarowaniu przestrzennym precyzyjnie określa obowiązkowy zakres treści planu miejscowego, $z$ drugiej zapisy planu nie powinny wchodzić w kwestie regulowane przez przepisy odrębne. Istnieje bowiem ryzyko powstania sprzeczności planu z przepisami odrębnymi przy zmianie przepisów powodująca konieczność każdorazowej aktualizacji planów w takim przypadku. Przykładem może być $\mathrm{np}$. kwestia przydomowych oczyszczalni ścieków lub szczelnych zbiorników na nieczystości (szamb) - w niektórych uchwalonych dawniej planach spotykane są zapisy ograniczające możliwość ich stosowania, jednakże zgodnie z aktualnie obowiązującymi przepisami kwestie te nie są przedmiotem ustaleń planu. Rola planów jest więc ograniczana do aspektów ściśle urbanistycznych.

\subsection{Przesłanki za szczegółowością zapisów planów}

Za wprowadzaniem zapisów szczegółowo definiujących możliwe sposoby zagospodarowania i parametry zabudowy przemawiają przede wszystkim przesłanki związane z ochroną ładu przestrzennego i dziedzictwa kulturowego oraz interesów lokalnych społeczności. Korzystne aspekty precyzyjnych regulacji planistycznych to w szczególności:

- ograniczenie ryzyka błędnego zrozumienia intencji planistów,

- ograniczenie wynikającej z pobudek ekonomicznych tendencji inwestorów do śrubowania parametrów zabudowy (intensywności, powierzchni lub wysokości zabudowy) dla maksymalnego wykorzystania potencjału działki,

- ochrona przed inwestycjami uciążliwymi dla sąsiedztwa (np. pod względem funkcji), ograniczającymi możliwość inwestowania sąsiadom (problem nasłonecznienia i przesłaniania) lub też takimi, które mogą zablokować potencjalne możliwości rozwoju infrastruktury,

- większa kontrola gminy nad rozwojem przestrzennym, a co za tym idzie większa przewidywalność zagospodarowania.

\subsection{Przesłanki za elastycznością zapisów planów}

Szczegółowe definiowanie zapisów planów miejscowych ma też jednak niekorzystne strony i może w niektórych sytuacjach hamować pozytywne zmiany przestrzenne. Należy bowiem pamiętać, że miejscowy plan zagospodarowania przestrzennego jest w polskim systemie prawnym dokumentem dość trwałym, którego ewentualna zmiana nie jest łatwa. Za elastycznością zapisów planów przemawiają zatem takie przesłanki, jak: 
- trudność zmiany raz uchwalonego planu, wynikająca z długotrwałości procedury planistycznej - w Poznaniu procedura sporządzenia miejscowego planu zagospodarowania przestrzennego trwa średnio ponad 3,5 roku4, a aktualnie są w opracowaniu 164 plany, z czego 43 to zmiany planów obowiązujących5,

- ryzyko szybkiego zdezaktualizowania się planu wobec szybko zmieniających się uwarunkowań: aktualnych trendów w architekturze, sytuacji na rynku nieruchomości, potrzeb inwestora lub społeczności miejskiej i innych,

- ograniczenie przez zbyt rygorystyczne zapisy planu swobody twórczej architektów, w ryzyko zablokowania niekonwencjonalnych i nowatorskich rozwiązań,

- większe ryzyko wystąpienia właścicieli z roszczeniami finansowymi wobec gminy z tytułu uniemożliwienia lub ograniczenia możliwości korzystania $z$ nieruchomości w sposób dotychczasowy (Ustawa 2003, art. 36 ust. 1) w przypadku zapisów mocno ograniczających możliwości zagospodarowania działki - elastyczne zapisy dają właścicielom możliwość większej swobody korzystania z prawa własności, mogą zatem liczyć na większe poparcie społeczne na etapie sporządzania planu, co przekłada się na mniejszą liczbę potencjalnych negatywnych opinii lub uwag składanych do projektu planu, a w konsekwencji skrócenie procedury planistycznej.

\subsection{Pozaplanistyczne narzędzia kształtowania przestrzeni}

W sytuacji, gdy ze wspomnianych wyżej powodów szczegółowe określenie kształtu planowanej zabudowy w planie miejscowym nie jest wskazane, można posłużyć się innymi metodami kształtowania przestrzeni. Są to tzw. narzędzia nieformalnego planowania, określane też mianem soft planning. (Kaczmarek, T.: 2017, ) Są one szczególnie przydatne na wczesnym etapie planowania inwestycji, gdy dokładne określenie w miejscowym planie zagospodarowania przestrzennego parametrów zabudowy często nie jest możliwe. Wypracowanie wspólnej wizji zagospodarowania przez miasto (gminę), inwestora (właściciela) i mieszkańców w drodze współpracy z wykorzystaniem narzędzi nieformalnego planowania (np. konsultacji, warsztatów itp.) może pozwolić na uniknięcie potencjalnych konfliktów społecznych. Pozwala to też na bardziej elastyczne podejście do kwestii planistycznych, zdejmując część ciężaru odpowiedzialności za kształt przestrzeni z zapisów w planach miejscowych.

Innym istotnym czynnikiem mogącym służyć kształtowaniu przestrzeni jest ekonomia. Wybór pewnych rozwiązań projektowych może wynikać z rachunku ekonomicznego i wówczas niekoniecznie musi być przedmiotem szczegółowych rozwiązań w planie miejscowym. Odpowiednio sformułowane zapisy planu, jak i dobrze zaprojektowane założenie urbanistyczne powinno sprzyjać takim rozwiązaniom, które zapewniając opłacalność inwestycji jednocześnie sprzyja dobrej jakości przestrzeni. Można wówczas mówić o samoregulacji przestrzeni pod wpływem czynników ekonomicznych.

\subsection{Rodzaje planów miejscowych ze względu na cel sporządzenia}

Ze względu na cel sporządzenia można wyróżnić następujące rodzaje miejscowych planów zagospodarowania przestrzennego:

- Plany ochronne - sporządzane w celu ochrony terenów cennych przyrodniczo (np. kliny zieleni), walorów krajobrazowych i widokowych (np. panoramy miasta) lub dziedzictwa kulturowego (np. historyczne centra miast lub dzielnice, układy dawnych wsi lub założeń dworskofolwarcznych). Często obejmują tereny wyłączone z zabudowy, a na terenach już zabudowa-

\footnotetext{
${ }^{4}$ średni czas trwania procedury od przyjęcia uchwały o przystąpieniu do sporządzenia miejscowego planu zagospodarowania przestrzennego do uchwalenia sporządzenia miejscowego planu zagospodarowania przestrzennego wynosi w Poznaniu 1326 dni wg danych Miejskiej Pracowni Urbanistycznej dla 256 miejscowych planów zagospodarowania przestrzennego uchwalonych w okresie od 16 czerwca 1998 r. do 8 stycznia 2019 r.

${ }^{5}$ wg Rejestru miejscowych planów zagospodarowania przestrzennego Miejskiej Pracowni Urbanistycznej w Poznaniu ze strony mpu.pl - stan na dzień 21 listopada 2018r.
} 
nych zawierają zapisy chroniące zastaną zabudowę i ograniczające do minimum rozbudowę lub wprowadzanie nowej zabudowy.

- Plany regulacyjne - tworzone w celu usprawnienia funkcjonowania i uporządkowania przestrzeni obszarów miasta powstałych np. bez planu w wyniku decyzji o warunkach zabudowy, bez wystarczającej infrastruktury, bądź też z występującymi konfliktami funkcjonalnymi (np. sąsiedztwo mieszkania - uciążliwy przemysł).

- Plany inwestycyjne - w celu uruchomienia terenów pod nową zabudowę: na terenach do tej pory niezabudowanych (np. odrolnionych) lub zrekultywowanych (remediacja) terenach po innych funkcjach (np. poprzemysłowych, pokolejowych, po gospodarstwach ogrodniczych itp.).

Każdy z wymienionych rodzajów planów wymaga zastosowania innego rodzaju zapisów, zastosowania podejścia bardziej restrykcyjnego lub bardziej elastycznego, w zależności od oczekiwanych efektów.

\section{MATERIAŁ I METODY BADAWCZE}

Jako materiał badawczy przyjęto miejscowe plany zagospodarowania przestrzennego opracowane w oparciu o aktualnie obowiązującą ustawę (Ustawa 2003), które w ostatnich latach podlegały zmianom lub też dla których zmiana jest aktualnie procedowana. Przystąpienie do zmiany planu świadczy o tym, że dotychczasowe zapisy planu, w tym stopień ich szczegółowości, się nie sprawdziły lub przestały się sprawdzać wobec aktualnej sytuacji przestrzennej i potrzeb. Takie określenie materiału badawczego pozwala na poznanie kierunków zmian w zapisach planów oraz ich przyczyn. Każda uchwała w sprawie przystąpienia do zmiany planu posiada uzasadnienie, które wskazuje m.in. wnioskodawcę, powody, oraz cele przeprowadzenia zmiany planu. Są to informacje, które są pomocne w określeniu zakładanych kierunków z zakresie uszczegółowienia lub uelastycznienia zapisów planu. W przypadku planów będących na bardziej zaawansowanym etapie opracowania, dysponujemy jeszcze bardziej szczegółowym materiałem dostarczającym informacji na ten temat w postaci projektów zmian planów oraz materiałów z konsultacji społecznych.

Z racji dostępności danych oraz doświadczenia zawodowego autora, który miał okazję pracować w Miejskiej Pracowni Urbanistycznej w Poznaniu, zdecydowano się na wybór zmian planów z obszaru miasta Poznania. W tym celu przeprowadzono kwerendę w rejestrze uchwalonych planów miejscowych oraz zmian planów będących w opracowaniu, obejmującą następujące dokumenty:

- teksty uchwał w sprawie miejscowego planu zagospodarowania przestrzennego wraz z załącznikiem graficznym (przed zmianami)

- teksty uchwał w sprawie miejscowego planu zagospodarowania przestrzennego wraz z załącznikiem graficznym (po zmianach)

- teksty uchwał w sprawie przystąpienia do zmiany miejscowego planu zagospodarowania przestrzennego wraz $z$ uzasadnieniem

- prezentacje z konsultacji społecznych, zawierające projekty planów, wyjaśnienie powodów przystąpienia do zmiany planu i planowanych kierunków zmian, rozstrzygnięcie wniosków i opinii do projektu planu

- projekty planów wyłożone do publicznego wglądu wraz ze zgłoszonymi uwagami i ich rozstrzygnięciem.

Zgromadzone powyższe informacje posłużyły do przeprowadzenia analizy porównawczej planów przed zmianami i po zmianach, obejmującej:

- stwierdzenie, czy zmiany i ich powody dotyczą stopnia szczegółowości zapisów planów,

- porównanie szczegółowości (restrykcyjności lub elastyczności) zapisów planów przed i po zmianach,

- znalezienie dominującej tendencji w formułowaniu zapisów planów (jeśli istnieje),

- określenie zależności kierunku zmian w planach w zależności od celu ich sporządzenia. 


\section{ANALIZA PRZYPADKÓW}

Zagadnienie szczegółowości zapisów przeanalizowano na przykładzie miejscowych planów zagospodarowania przestrzennego w Poznaniu, które podlegały zmianom w ostatnich latach, bądź też dla których przystąpiono do sporządzenia zmiany. Do analizy wzięto 24 aktualnie procedowane zmiany planów ${ }^{6}$, w szczególności przyglądając się uzasadnieniom uchwał o przystąpieniu do sporządzenia oraz, tam gdzie to możliwe, projektom planów przedstawionym na konsultacjach społecznych. W kilku przypadkach mieliśmy do czynienia z planami zmienianymi kilkukrotnie.

Analizując przyczyny przystąpienia do przebadanych zmian planów, stwierdzono:

- 17 przypadków zmian przeprowadzanych w celu uelastycznienia zapisów,

- 2 przypadki zmian przeprowadzanych w celu zaostrzenia zapisów,

- 1 przypadek, w którym uelastycznienie części zapisów zrekompensowano zapisami chroniącymi przestrzeń w inny sposób,

- 3 przypadki zmian neutralnych, w tym dostosowujących zapisy mpzp do zmiany studium,

- w 1 przypadku nie udało się dotrzeć do uzasadnienia zmiany.

Spośród wymienionych zmian miejscowych planów zagospodarowania przestrzennego wybranych zostało klika przykładów ilustrujących następujące sytuacje:

- przypadki, w których zapisy zbyt restrykcyjne nie sprawdziły się i postanowiono zmienić plan w celu ich uelastycznienia,

- przypadki, w których zapisy były zbyt elastyczne i pojawiła się konieczność ich uszczegółowienia,

- przypadki zastosowania rozwiązań pośrednich, w tym takich, gdzie uelastycznienie jednych zapisów było rekompensowane uszczegółowieniem innych.

\section{1. przykłady uelastycznienia zapisów}

Przykładem lokalizacji, w której zapisy planu okazały się zbyt szczegółowe, może być kwartał położony między ulicami Hetmańską, Górecką, Krauthofera i Dmowskiego w Poznaniu. Potrzeba uelastycznienia regulacji planistycznych zaszła w tym miejscu w ostatnich latach dwukrotnie. W 2005 r. uchwalony został dla tego obszaru Miejscowy plan zagospodarowania przestrzennego terenu w rejonie ulic Hetmańskiej, Dmowskiego, J. Krauthofera - Krotowskiego i projektowanej Nowej Opolskiej w Poznaniu (Miejscowy plan 2005) (ryc. 3Fig. ), przewidujący realizację zespołu zabudowy handlowo-usługowej z dokładnie określoną lokalizacją zabudowy i takich elementów jak: części budynków o podwyższonej wysokości, dominanty i akcenty architektoniczne, prześwity w zabudowie, szpalery drzew, zbiorniki wodne, drogi wewnętrzne ze zjazdami dla ruchu osobowego i towarowego itp. W wyniku rezygnacji z realizacji tej koncepcji plan się zdezaktualizował, a ze względu na wspomnianą szczegółowość uniemożliwiał realizację jakiejkolwiek koncepcji odbiegającej od pierwotnego projektu. W związku z tym już 5 lat później, w 2010 r. uchwalona została zmiana miejscowego planu zagospodarowania przestrzennego (Zmiana miejscowego planu 2010) terenu w rejonie ulic Hetmańskiej, Dmowskiego, J. Krauthofera - Krotowskiego i projektowanej Nowej Opolskiej w Poznaniu (ryc. 4Fig. ), o dużo bardziej ogólnych zapisach. Zrezygnowano z większości wyżej wymienionych szczegółowych regulacji, pozostawiając jedynie jedną drogę wewnętrzną, strefę przestrzeni publicznej, a wskazanie podwyższonych części budynków zastąpiono jedną strefą wyższej zabudowy. W 2018 r. na części kwartału przystąpiono do sporządzenia kolejnego miejscowego planu zagospodarowania przestrzennego „Rejon ulic Hetmańskiej i Góreckiej" w Poznaniu (Uchwała 2018, 1) - ta ostatnia zmiana spowodowana została m. in. niemożnością zagospodarowania terenu zgodnie $z$ obowiązującym obecnie planem ze względu na brak dostępu do drogi publicznej do czasu realizacji projektowanej ulicy Nowej Opolskiej. Dotychczasowy zapis de facto uzależniał możliwość realizacji inwestycji od powstania infrastruktury, przez co tereny te mogłyby pozostać zamrożone na długie lata (w miejscowym planie zagospodarowania prze-

\footnotetext{
${ }^{6} \mathrm{Na}$ podstawie rejestru miejscowych planów zagospodarowania przestrzennego z dnia 21 listopada 2018 r., treści uchwał wraz z uzasadnieniami oraz prezentacji z konsultacji społecznych zamieszczonych na stronie internetowej Miejskiej Miejskiej Pracowni Urbanistycznej w Poznaniu - www.mpu.pl
} 
strzennego nie ma możliwości zapisania etapowania, gdyż jest on prawem miejscowym, a nie planem realizacyjnym). Przewidywane zmiany mają też służyć wzrostowi wartości i atrakcyjności nieruchomości przeznaczonej pod funkcje usługowe, należy się zatem spodziewać dalszego uelastycznienia zapisów.

Innym przykładem może być Miejscowy plan zagospodarowania przestrzennego "Obszar Staromiejski w Poznaniu" z 2002 r. (Miejscowy plan 2002) Plan ten (uchwalony jeszcze przed wejściem w życie obecnie obowiązującej ustawy o planowaniu i zagospodarowaniu przestrzennym), pomyślany jako plan ochronny wprowadzał szereg bardzo szczegółowych zapisów. Określał $\mathrm{m}$. in. dla niektórych terenów procentowy udział funkcji (mieszkaniowej i usługowej), co miało na celu zapobieżenie wyludnianiu się historycznego centrum itworzeniu się monofunkcji usługowej. W przypadku niektórych działek taki zapis zablokował w praktyce możliwość ich zagospodarowania. Podobny skutek miał brak dopuszczenia dla niektórych terenów parkingów podziemnych. Stąd w następnych latach przystąpiono do licznych nowelizacji planu dla poszczególnych fragmentów (12 planów uchwalonych do roku 2018, przystąpienie do kolejnych 4), a w 2018 r. przystąpiono do zmiany całego planu (Uchwała 2018, 2).

\section{2. przykłady uszczegółowienia (ZAOSTRZENIA) zapisów}

Potrzeba zaostrzenia zapisów zachodzi zazwyczaj tam, gdzie istnieje ryzyko zbyt dowolnej interpretacji. Tak jest $\mathrm{m}$. in. w sytuacjach nietypowych, wymagających dodatkowego dookreślenia wymagań.

Takimi są np. tereny o zróżnicowanej rzeźbie, dające duże pole do interpretacji zapisów w zakresie wysokości budynków. W takich sytuacjach nie zawsze sprawdza się tradycyjny sposób definiowania wysokości budynku w metrach lub liczbie kondygnacji nadziemnych. Jeszcze bardziej skomplikowana sytuacja jest w przypadku, gdy intencją projektantów jest wprowadzenie zabudowy o zróżnicowanej wysokości. Zapisy, mówiące o „zabudowie kaskadowej” (lub podobnie sformułowane) są w tym przypadku nieprecyzyjne. Dlatego też ciekawym rozwiązaniem jest zdefiniowanie stref o dopuszczalnej wysokości bezwzględnej zabudowy określonej w metrach nad poziom morza. W Poznaniu z taką sytuacją mamy do czynienia np. w opracowywanym projekcie miejscowego planu zagospodarowania przestrzennego rejonu Minikowa w Poznaniu (Uchwała 2005), obejmującego tereny położone na skarpie wzdłuż rzeki Warty.

Wprowadzenie bardziej restrykcyjnych zapisów może też być spowodowane dążeniem do uporządkowania przestrzeni, $w$ tym do uczytelnienia układu urbanistycznego. $Z$ taką sytuacją mamy $\mathrm{np}$. do czynienia w przypadku projektu miejscowego planu zagospodarowania przestrzennego „Łacina - Południe - część B” w Poznaniu (Uchwała 2016), w którym zaproponowano zmianę niektórych linii zabudowy $z$ nieprzekraczalnych na obowiązujące $w$ celu wytworzenia pierzei wzdłuż ulic. (Projekt Łacina - Południe - część B 2018).

\subsection{Rozwiązania pośrednie}

Często konieczne jest znalezienie rozwiązań pośrednich, godzących pozornie przeciwstawne interesy, jakimi są ochrona układu przestrzennego i jednocześnie zapewnienie możliwości adaptacji zabudowy do nowych potrzeb. Dobrym przykładem takiego działania są miejscowe plany zagospodarowania przestrzennego dla poznańskich osiedli modernistycznych, położonych na Piątkowie, Winogradach i Ratajach. Wypracowano w nich charakterystyczny sposób definiowania linii zabudowy - jako maksymalnych nieprzekraczalnych, odsuniętych na niewielką odległość od istniejących elewacji budynków. Taki sposób kształtowania linii zabudowy, pozwala zachować pierwotnie zaprojektowany układ przestrzenny budynków i zabezpieczyć przed niekontrolowanym dogęszczaniem osiedli, a jednocześnie nie blokuje ich koniecznej modernizacji.

Innym przykładem kompromisu pomiędzy elastycznością a restrykcyjnością zapisów planów miejscowych są sytuacje, gdy uelastycznienie pewnych zapisów jest rekompensowane wprowadzeniem innych ograniczeń. Jako przykład można podać opracowywaną obecnie zmianę miejscowego planu zagospodarowania przestrzennego dla terenu Międzynarodowych Targów Poznańskich (Uchwała 2017). W stosunku do aktualnie obowiązującego planu (Miejscowy plan 2011) 
w projekcie przedstawionym na konsultacjach społecznych (Projekt Miejscowego planu 2018) zaproponowano $\mathrm{m}$. in. zmniejszenie stref zakazu zabudowy, co mogłoby skutkować ograniczeniem widoczności dominanty wysokościowej, jaką jest iglica targowa (Pawilon $\mathrm{nr} 11$ ). Aby temu przeciwdziałać, wprowadzona została strefa ochrony widoku na dominantę.

\section{PODSUMOWANIE I WNIOSKI}

Po przeanalizowaniu wybranych zmian miejscowych planów zagospodarowania przestrzennego w Poznaniu można poczynić następujące spostrzeżenia:

- szczegółowość zapisów planów podlega ograniczeniom prawnym i postępującej standaryzacji,

- podejście do szczegółowości jest uzależnione od celu sporządzenia planu - większa szczegółowość zapisów jest pożądana w przypadku planów ochronnych i regulacyjnych, większa elastyczność w przypadku planów inwestycyjnych,

- spośród procedowanych obecnie zmian planów w Poznaniu zdecydowana większość ma na celu uelastycznienie ich zapisów,

- zbyt duża szczegółowość zapisów planów może prowadzić do zablokowania inwestycji w przypadku planów inwestycyjnych, lub do uniemożliwienia modernizacji albo uzupełnienia zabudowy w przypadku planów ochronnych i regulacyjnych,

- większa szczegółowość zapisów np. w zakresie definiowania linii zabudowy jest dobrym narzędziem uczytelnienia kompozycji urbanistycznej, szczególnie pomocnym w przypadku planów regulacyjnych,

- uelastycznienie jednych zapisów można rekompensować wprowadzeniem innych uszczegółowień, np. w celu ochrony wartościowych elementów przestrzeni.

Ogólnie rzecz biorąc, należy stwierdzić, że stopień szczegółowości definiowania poszczególnych zapisów w planach miejscowych powinien być określany indywidualnie w zależności od przypadku, biorąc pod uwagę z jednej strony cele, jakie mają być osiągnięte przez uchwalenie planu, a z drugiej strony ryzyka związane z wprowadzeniem danych zapisów. W najbliższych latach można się spodziewać zmian w podejściu do szczegółowości formułowania zapisów w planach miejscowych, spowodowanych wprowadzeniem nowego instrumentu prawnego w postaci decyzji o lokalizacji inwestycji mieszkaniowej. Wpływ stosowania tego rodzaju decyzji na praktykę tworzenia miejscowych planów zagospodarowania przestrzennego nie jest jeszcze znany i powinien być przedmiotem przyszłych badań.

\section{BIBLIOGRAPHY}

Bonenberg, W.: 2015, Planning Documents As an Element of Modernizing the Urban Structure of the Poznan Metropolitan Area, Civil and Environmental Engineering Reports, rok 2015, nr 17(2), 25-32

Ciesiółka, P., Rogatka, K.: 2015, Rola miejscowych planów zagospodarowania przestrzennego w procesie rewitalizacji miast na przykładzie metropolii Poznań, Problemy Rozwoju Miast - Kwartalnik Naukowy Instytutu Rozwoju Miast, rok XII, zeszyt IV/2015, 27-36

Dąbrowska-Milewska G.: 2010, Czy w polsce potrzebne są standardy urbanistyczne dla terenów mieszkaniowych?, Architecturae et Artibus, 1/2010, 12-16 
Izdebski, W., Śleszyński, P., Malinowski, Z., Kursa, M.: 2018, Analiza morfometryczna planów miejscowych w Polsce, Infrastruktura i ekologia terenów wiejskich, II/1/2018, 331-347

Kaczmarek, T.: 2017, Nieformalne planowanie przestrzenne - przesłanki, cele i instrumenty. Przykład planowania rozwoju obszaru metropolitalnego Poznania, Biuletyn Komitetu Przestrzennego Zagospodarowania Kraju Polskiej Akademii Nauk, zeszyt 266, rok 2017, 73-92

Miejscowy plan zagospodarowania przestrzennego "Obszar Staromiejski w Poznaniu" (symbol Os) - Uchwała nr XCIII/1055/III/2002 Rady Miasta Poznania z dnia 9 lipca 2002 r.

Miejscowy plan zagospodarowania przestrzennego „Międzynarodowych Targów Poznańskich” w Poznaniu (symbol Sm) - Uchwała nr XVIII/216/VI/2011 Rady Miasta Poznania z dnia 20 września 2011r.

Miejscowy plan zagospodarowania przestrzennego w rejonie ulic: Hetmańskiej, R. Dmowskiego, J. Krauthofera - Krotowskiego i projektowanej Nowej Opolskiej w Poznaniu z 2005 r. (symbol Gb) Uchwała nr LXXI/746/IV/2005 Rady Miasta Poznania z dnia 7 czerwca 2005r.

Miejska Pracownia Urbanistyczna. Prezentacja projektu miejscowego planu - konsultacje społeczne II. 17.12.2018. http://www.mpu.pl/repozytorium/457_Lacina_b_II\%20konsultacje\%20spoLeczne_prezentacja.pdf Dostęp dnia 22.01.2019

Nowak, M. J.: 2015, Nieefektywność decyzji o warunkach zabudowy i zagospodarowania terenu w kształtowaniu ładu przestrzennego a działania organów administracji publicznej, Biuletyn Komitetu Przestrzennego Zagospodarowania Kraju Polskiej Akademii Nauk, zeszyt 257/258, rok 2015, 46-57

Projekt Miejscowego planu zagospodarowania przestrzennego „Międzynarodowe Targi Poznańskie” w Poznaniu, proj. zespół pod kierunkiem A. Kijowskiego, zaprezentowany na II konsultacjach społecznych prezentacja opublikowana 30.10.2018 na stronie internetowej Miejskiej Pracowni Urbanistycznej pod adresem: http://www.mpu.pl/repozytorium/432_MTP\%20II\%20konsultacje.pdf. dostęp dnia 01.01.2019

Projekt Miejscowego planu zagospodarowania przestrzennego „Łacina - Południe - część B” w Poznaniu, proj. K. Derda, S. Głowacki, Ł. Brodnicki, D. Marcinek. Miejska Pracownia w Poznaniu 2018

Śleszyński P.: 2015, Błędy polskiej polityki przestrzennej i krajobrazowej oraz propozycje ich naprawy. Problemy Ekologii Krajobrazu. Tom XL: 27-44

Stangel, M.: 2013, Kształtowanie współczesnych obszarów miejskich w kontekście zrównoważonego rozwoju, Wydawnictwo Politechniki Śląskiej, Gliwice

Uchwała nr LXIII/1157/VII/2018 Rady Miasta Poznania z dnia 6 marca 2018r. w sprawie przystąpienia do sporządzenia miejscowego planu zagospodarowania przestrzennego „Rejon ulic Hetmańskiej i Góreckiej” w Poznaniu

Uchwała nr LXXIV/1395/VII/2018 Rady Miasta Poznania z dnia 16 października 2018r. w sprawie przystąpienia do sporządzenia miejscowego planu zagospodarowania przestrzennego „Stare Miasto” w Poznaniu

Uchwała nr LXXVIII/858/IV/2005 Rady Miasta Poznania z dnia 27 września 2005r. w sprawie przystąpienia do sporządzenia miejscowego planu zagospodarowania przestrzennego rejonu Minikowa w Poznaniu

Uchwała nr XLVII/810/VII/2017 Rady Miasta Poznania z dnia 25 kwietnia 2017r. w sprawie przystąpienia do sporządzenia miejscowego planu zagospodarowania przestrzennego „Międzynarodowe Targi Poznańskie" w Poznaniu

Uchwała nr XXXIII/517/VII/2016 Rady Miasta Poznania z dnia 12 lipca 2016r. w sprawie przystąpienia do sporządzenia miejscowego planu zagospodarowania przestrzennego „Łacina - Południe” w Poznaniu.

Ustawa z dnia 27 marca 2003 o planowaniu i zagospodarowaniu przestrzennym (Dz. U. Nr 80, poz. 717, z późniejszymi zmianami, t.j. Dz. U. z 2017 r. poz. 1073, 1566, z 2018 r. poz. 1496, 1544)

Ustawa z dnia 5 lipca 2018 r. o ułatwieniach w przygotowaniu i realizacji inwestycji mieszkaniowych oraz inwestycji towarzyszących (Dz.U. 2018 poz. 1496)

Ustawa z dnia 5 lipca 2018 r. o ułatwieniach w przygotowaniu i realizacji inwestycji mieszkaniowych oraz inwestycji towarzyszących (Dz.U. 2018 poz. 1496)

Zachariasz, I., Nelicki, A.: 2008, Skuteczność planowania przestrzennego na poziomie lokalnym a partycypacja społeczna, Zarządzanie Publiczne, nr 2(4), rok 2008, 97-108

Zmiana miejscowego planu zagospodarowania przestrzennego w rejonie ulic: Hetmańskiej, R. Dmowskiego, J. Krauthofera - Krotowskiego i projektowanej Nowej Opolskiej w Poznaniu z 2010 r. (symbol Gc) Uchwała nr LXXX/1210/V/2010 Rady Miasta Poznania z dnia 9 listopada 2010r. 


\section{AUTHOR'S NOTE}

PhD Engineer in Architecture, assistant professor in Division of Work Places and Recreation, Institute of Architecture and Physical Planning in Faculty of Architecture in Poznan University of Technology. Field of his research include spatial planning and urban planning issues in the context of energy efficiency of buildings.

\section{O AUTORZE}

Doktor inżynier architekt, adiunkt w Zakładzie Architektury Miejsc Pracy i Rekreacji Instytutu Architektury i Planowania Przestrzennego na Wydziale Architektury Politechniki Poznańskiej. Jego zainteresowania naukowe obejmuja planowanie przestrzenne oraz zagadnienia urbanistyczne w kontekście efektywności energetycznej budynków.

Contact | Kontakt: wojciech.skorzewski@put.poznan.pl 